\title{
THE IMPLICATIONS OF FISH AQUACULTURE ON THE QUALITY OF THE SEDIMENTS OF THE EARTHEN PONDS AT DELTA BREEDING STATION
}

\author{
Abbas, H. H. ${ }^{1}$; Esmat A. Nofal ${ }^{1}$; M. Abdel Meguid ${ }^{2}$, Y. M. Ali ${ }^{3}$ and \\ Maha M. Ali ${ }^{4}$
}

1. Fac. of Agric., Banha University.

2. Environmental Research Institute- National Water Research Center.

3.Channel Maintenance Research Institute- National Water Research Center.

4.Central Laboratory for Environmental Quality Monitoring- National Water Research Center.

\begin{abstract}
Egyptian aquaculture has been started with the use of traditional extensive and semi-intensive techniques. Rapid aquaculture development has occurred in recent years, after it had been identified as the best answer to reduce the increasing gap between supply and demand for fish. However, there is much concern about the increasing of the nutrient load and trace elements in sediment of earthen ponds due to the process of rearing fish of different sizes and ages. Based on this statement, the present study was conducted to investigate the characteristics of the bottom sediments of the earthen ponds at the Delta Breeding Station (DBS) and identifying problems raised from different activities especially that cause sediment pollution during rearing the fish, grass carp.

Results showed that the texture of the sediment in earthen pond was slightly similar. It ranged from sandy loam to loam. However, during rearing the grass carp in different sizes in the earthen ponds, the quality of the sediment has been widely changed after 3, 6 and 9 months from the stocking of fish. With increasing the period of stocking of fish in the earthen ponds, the values of $\mathrm{pH}$ have been statistically decreased, while the values of $(\mathrm{EC}),\left(\mathrm{HCO}_{3}{ }^{-}\right),\left(\mathrm{Ca}^{2+}\right),\left(\mathrm{K}^{+}\right),\left(\mathrm{Mg}^{2+}\right),\left(\mathrm{Na}^{+}\right),\left(\mathrm{Cl}^{-}\right),\left(\mathrm{NO}_{2}^{-}\right)$, $\left(\mathrm{NO}_{3}{ }^{-}\right),\left(\mathrm{NH}_{4}-\mathrm{H}^{+}\right),\left(\mathrm{PO}_{4}{ }^{3+}\right),\left(\mathrm{SO}_{4}{ }^{2+}\right)$ ions and the heavy metals $(\mathrm{Ba}),(\mathrm{Cd}),(\mathrm{Co}),(\mathrm{Cr})$, $(\mathrm{Cu}),(\mathrm{Fe}),(\mathrm{Mn}),(\mathrm{Ni}),(\mathrm{Pb}),(\mathrm{V})$ and $(\mathrm{Zn})$ have been statistically increased. Also the percentage of organic matter (O.M) increased. In addition, the sediments in earthen ponds which were stocked with the breeders of grass carp were characterized by having the higher values of anions, cations and heavy metals in the sediment more than the sediment of the earthen ponds which stocked with fingerlings of grass carp. This is mainly attributed to the feeding process.

Key words: fish aquaculture, sediments, earthen ponds.
\end{abstract}

\section{INTRODUCTION}

A large number of fish farms have been established in Egypt. Most of them are classified as semi-intensive brackish water farms (El Atfy and Abdel-Meguid, 2012). There are benefits from such aquacultures that include increases in farm productivity and profitability without any net increase in water consumption. However, there is much concern about an environmental hazard (Hektoen et al., 1995; Capone et al., 1996; Ali and Abdin, 2003; Jawad et al., 2004; Abdel-Meguid et al. 2005; Ali et al. 2006).

Previous studies have shown that intensive fish aquaculture can lead to higher proportion of organic materials and fertilizers such as ammonia, 
nitrate and phosphate compounds as well as the high proportion of heavy elements in the water and sediments (Madhav and Lin, 1996; Ali and Abdin, 2003; Bakry et al., 2004; Jawad et al., 2004; Ali et al., 2006; Tohamy et al., 2006 and El-Kholy, 2013). The presence of nutrients such as phosphates and nitrates can cause some inconvenience, such as the spread of various types of algae as well as the formation of a suitable environment for the growth and spread of many diseases that can cause the fish mortalities (Abdel-Meguid, 1998 and 1999).

Prowse (1971), Stanley (1974), ILACO (1983), and Bakry et al., (2004) stated that fertilization scheme as well as consumption of food and deposition of grass carp fecal matter may further enhance the phytoplankton and the filamentous algal productions through increasing the nutrients availability. Such nutrients may constrain water use in ponds by enhancing the process of eutrophication and increasing the inorganic and organic sedimentation and causing pollution to both water and sediment, as a result, anoxia may be established in the water column a few centimeters from the surface, and zooplanktons, benthos and fish particularly diminish (Boyd, 1971; Carter and Hestand, 1977; Von Donk et al., 1993; Schriver et al., 1995; Ali and Abdin, 2003; Ali et al., 2006).

In case of presence contaminants, the suspended sediment can mainly contribute to degraded water quality and cause adverse effects on critical habitats especially in the fish farms. Sediment suspended in the water column can reduce water clarity and increase light attenuation such that light penetration is below that needed to support healthy planktonic communities in ponds which are an important biological resource for fish feeding. For example, sediment can carry toxic contaminants, pathogens and phosphorous $(P)$ that negatively affect the fish production. Excessive sedimentation also can degrade the vitality of benthic (bottom-dwelling) organisms and decrease their populations (CBP, 2006).

From this point of view, in polluted water, sediments are increasingly recognized as the most important sink of contaminants and as a reservoir and possible future source of pollutants. One from those pollutants are heavy metals which may adversely affect the soil ecosystem safety, not only fish production and water quality, but also the humen health (Adriano, 2001; Zhou et al., 2004). Heavy metals are elements that have metallic properties, atomic number over 20 (Nieboer and Richardson, 1980) and a density higher than $5.0 \mathrm{~g} / \mathrm{cm}^{3}$ (Sanita di Toppi and Gabbrielli, 1999). Heavy metals, even at trace concentration, can cause serious problems to all organisms and heavy metal bioaccumulation in the food chain can be highly dangerous (Sanita di Toppi and Gabbrielli, 1999).

The primary goal of the present study was to improve the fish productivity through reducing the pollutant loads within the sediment of the earthen ponds. To achieve this goal, to investigate the characteristics of the bottom sediments within the earthen pond in the Delta Breeding Station (DBS) and identifying problems raised from different activities in (DBS) especially that cause sediment pollution. 


\section{MATERIALS AND METHODS}

Study area:

Delta Breeding Station (DBS) was established by Channel Maintenance Research Institute (CMRI) in 1981. (DBS) is locating at ElKanater El-khairiea. It contains 11 rearing earthen ponds. These ponds have an average depth of 1.5 meter, all ponds are filled from the Nile River, and the dimension of the ponds and their arrangement are presented in Table 1 and Figure 1. The benefit of such ponds is to provide the Ministry of Water Resources and Irrigation (MWRI) with about $1 / 2$ million of fingerlings of grass carp to be stocked in waterways for biological control against the aquatic weeds mainly the submerged aquatic weeds. The quality of the water supply from the Nile River is shown in Table 2. In the production ponds, fry are reared till the stocking weight $(10-50 \mathrm{~g})$. They feed on artificial pellet which contains fish-meal (20-30\%), soya meal (15\%) and sorghum (20\%). The concentrations of heavy metals within this pellet are presented in Table (3). Later on, pond feeding is carried out with grass, maize and clover.

Table 1: Dimensions of the earthen ponds and their uses at the Delta Breeding Station (DBS)

\begin{tabular}{|l|c|c|c|c|c|}
\hline Pond & $\begin{array}{c}\text { Length } \\
(\mathrm{m})\end{array}$ & $\begin{array}{c}\text { Width } \\
(\mathrm{m})\end{array}$ & $\begin{array}{c}\text { pond area } \\
(\mathrm{m} 2)\end{array}$ & Type of fish & Type of feed \\
\hline D1 & 25.00 & 8.90 & 222.5 & fingerlings & pellets \\
\hline D2 & 25.00 & 8.80 & 220.0 & fingerlings & pellets \\
\hline D3 & 25.70 & 8.80 & 226.2 & fingerlings & pellets \\
\hline D4 & 26.20 & 8.80 & 230.5 & fingerlings & pellets \\
\hline D5 & 28.00 & 8.15 & 228.2 & fingerlings & pellets \\
\hline D6 & 19.35 & 7.70 & 149.5 & fingerlings & pellets \\
\hline D7 & 38.30 & 18.10 & 693.3 & breeders & Green feed \\
\hline D8 & 40.00 & 8.65 & 346.0 & breeders & Green feed \\
\hline D9 & 31.00 & 17.30 & 536.0 & fingerlings & pellets \\
\hline D10 & 71.00 & 17.30 & 1228.0 & fingerlings & pellets \\
\hline D11 & 71.00 & 17.30 & 1228.0 & fingerlings & pellets \\
\hline
\end{tabular}

Table 2: Chemical properties of the water supply at the Delta Breeding Station (DBS)

\begin{tabular}{|c|c|}
\hline property & $\begin{array}{c}\text { Nile River } \\
\text { El-Kanater El-khairiea }\end{array}$ \\
\hline $\mathrm{pH}$ & 8.04 \\
\hline$\left(\mathrm{dSm}^{-1}\right)$ & 0.43 \\
\hline$\left(\mathrm{mg} \mathrm{L}^{-1}\right)$ & 25 \\
\hline$\left(\mathrm{mg} \mathrm{L}^{-1}\right)$ & 10.3 \\
\hline$\left(\mathrm{mg} \mathrm{L}^{-1}\right)$ & 17.4 \\
\hline$\left(\mathrm{mg} \mathrm{L}^{-1}\right)$ & 30.6 \\
\hline $\mathrm{NH}_{4}-\mathrm{H}^{+} \quad\left(\mathrm{mg} \mathrm{L}^{-1}\right)$ & 0.025 \\
\hline$\left(\mathrm{mg} \mathrm{L}^{-1}\right)$ & 0 \\
\hline $\mathrm{HCO}_{3}^{-} \quad\left(\mathrm{mg} \mathrm{L}^{-1}\right)$ & 175.5 \\
\hline$\left(\mathrm{mg} \mathrm{L}^{-1}\right)$ & 35.5 \\
\hline$\left(\mathrm{mg} \mathrm{L}^{-1}\right)$ & 19.9 \\
\hline $\mathrm{NO}_{3}^{-} \quad\left(\mathrm{mg} \mathrm{L}^{-1}\right)$ & 0.12 \\
\hline$\left(\mathrm{mg} \mathrm{L}^{-1}\right)$ & 0.15 \\
\hline$\left(\mathrm{mg} \mathrm{L}^{-1}\right)$ & 0.006 \\
\hline$\left(\mathrm{mg} \mathrm{L}^{-1}\right)$ & 0.019 \\
\hline$\left(\mathrm{mg} \mathrm{L}^{-1}\right)$ & 0.126 \\
\hline$\left(\mathrm{mg} \mathrm{L}^{-1}\right)$ & 0.105 \\
\hline$\left(\mathrm{mg} \mathrm{L}^{-1}\right)$ & 0.017 \\
\hline$\left(\mathrm{mg} \mathrm{L}^{-1}\right)$ & 0.002 \\
\hline$\left(\mathrm{mg} \mathrm{L}^{-1}\right)$ & 0.005 \\
\hline
\end{tabular}




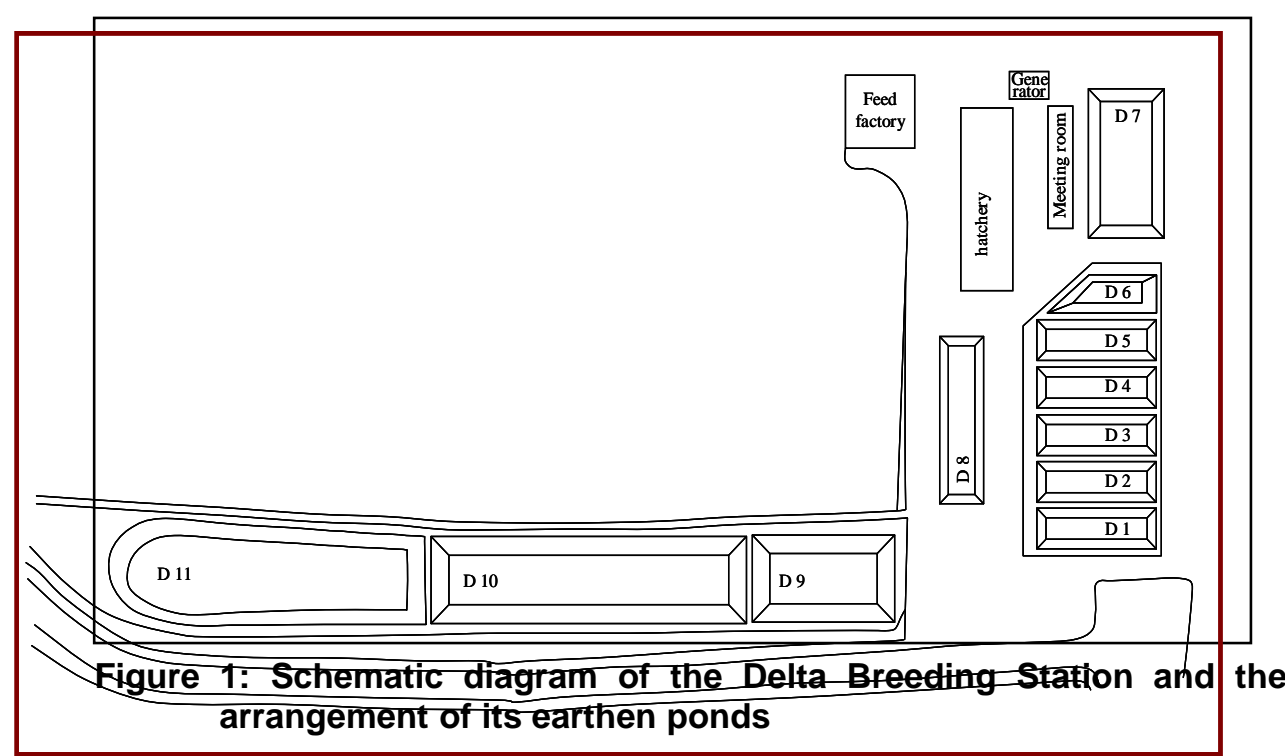

Table 3: Concentrations of different heavy metals within the artificial pellets $\left(\mathrm{mg} \mathrm{kg}^{-1}\right)$

\begin{tabular}{|l|l|}
\hline Element & Concentration $\left(\mathrm{mg} \mathrm{kg}^{-1}\right)$ \\
\hline $\mathrm{Cu}$ & 6.94 \\
\hline $\mathrm{Zn}$ & 10.48 \\
\hline $\mathrm{Fe}$ & 155.1 \\
\hline $\mathrm{Mn}$ & 38.93 \\
\hline $\mathrm{pb}$ & 4.197 \\
\hline $\mathrm{Cd}$ & 1.9 \\
\hline $\mathrm{Ni}$ & 5.32 \\
\hline
\end{tabular}

\section{The experimental work:}

An experimental work was conducted at the Delta Breeding Station. The sediment samples were collected from 11 earthen ponds in (DBS) as shown in Table 1 which describes the main characteristics of each pond and its use.

Surface sediments were chosen for this study as this layer controls the exchange of metals between sediments and water (EI Nemr et al., 2006). The surface sediments were sampled randomly, carefully taken with sediment sampler from the top of sediment and collected as composite samples ( 3 grabs) from 11 earthen ponds after 3,6 months of stocking and after 9 months (after fish fingerlings harvesting).

the laboratory.

The sediments were kept cool in an icebox during transportation to Laboratory analyses:

The chemical parameters $(\mathrm{pH}$, carbonate, bicarbonate, total alkalinity, electrical conductivity and O.M) were measured at $1: 2$ soil to water ratio extracts as soon as the samples reached the laboratory. For other 
analyses, the surface sediments were air-dried, homogenized using pestle and mortar, passed through a 2-mm mesh screen and stored in polyethylene bags. Percentage of organic matter was determined by Walkley-Black method as described by the Recommended by Chemical Soil Test Procedures, (1998).

Mechanical analysis was performed for sediment samples using hydrometer method according to (Gee and Bauder 1994).

For the determination of heavy metals, approximately $2 \mathrm{~g}$ of each sample was digested with $15 \mathrm{ml}$ of aqua-regia (1: $3 \mathrm{HCl}^{\mathrm{HNO}} \mathrm{HN}_{3}$ ) in a Teflon bomb for $2 \mathrm{~h}$ at $120{ }^{\circ} \mathrm{C}$. After cooling, the digested samples were filtered and kept in plastic bottles. Radojevic and Bashkin (1999) stated that aqua regia is adequate for extraction of total metals in soil sample and is widely used in most soil analysis laboratories. Heavy metals (aluminum, arsenic, barium, cadmium, cobalt, chromium, copper, iron, manganese, molybdenum, nickel, lead, antimony, selenium, vanadium and zinc) and base cations (calcium, potassium, magnesium, sodium and ammonium) and base anions (nitrite, nitrate, phosphate, sulfate and chloride) were analyzed using standard methods of APHA (1998).

\section{Statistical Analysis}

The relationships among the values of both physical and chemical parameters within the sediment in earthen ponds after 3,6 month of stocking and after 9 month (after fish fingerling harvesting) were tested using ClassifyHierarchical Cluster Analysis (Dendrogram). To identify problems raised from different activities in the fish farm especially those cause sediment pollution, the physical and chemical parameters were evaluated after 3,6 and 9 months from the fish stocking by using the statistical analysis (t test) " $p=0.05 "$.

\section{RESULTS AND DISCUSSION}

The present results revealed that the texture in earthen pond sediments was slightly similar as shown in Table 4. It ranged from sandy loam to loam. The textures of the sediments were sandy loam in ponds (D1, D2, D3, D4, D5, D6, D9, D10 and D11) while they were loamy in the ponds (D7 and D8). These textures of sediment meet the requirements of pond soil which include water-tight that is important in maintaining good water fertility and low turbidity that is principle for normal growth of fish and food organisms. (Yuan, 2012) mentioned that sandy soil has the problem of seepage, which can cause water current in pond and difficulty in maintaining fertility of water. Clay soil has the problem of high turbidity when there is wave in the pond due to the too fine soil particle.

Concerning the characteristics for the sediments, the results presented in Table 5, 6 and 7 showed that the sediments within the earthen ponds at (DBS) were widely different. These wide variations may depend on many factors which may include pollutants, either naturally present or added to the feed (components) before, during or after processing or regenerating within the feed by decomposition, water and its drainage system and nutrients in the 
effluent waters which are primarily derived from feed waste (fines/dust and feed not eaten by fish), and excreted and faecal wastes. Moreover, different fishes have different biological characteristics. Such characteristics change with the stage of their growth and development. So many biological characteristics of grass carp fry and fingerling are very different from their adults, e.g. diet composition, feeding feature, and environmental requirements etc. Therefore, it is very important to be aware about such characteristics for understanding the rearing technique.

Table 4: Texture of sediments in earthen ponds at Delta Breeding Station (DBS)

\begin{tabular}{|l|c|c|c|c|}
\hline Ponds & Sand $(\%)$ & Silt $(\%)$ & Clay (\%) & Textural class \\
\hline D1 & 75.55 & 10.32 & 14.13 & Sandy loam \\
\hline D2 & 72.13 & 15.18 & 12.69 & Sandy loam \\
\hline D3 & 68.32 & 13.55 & 18.33 & Sandy loam \\
\hline D4 & 74.15 & 8.85 & 17.00 & Sandy loam \\
\hline D5 & 70.69 & 15.21 & 14.10 & Sandy loam \\
\hline D6 & 79.12 & 7.58 & 13.30 & Sandy loam \\
\hline D7 & 50.12 & 36.14 & 13.74 & Loam \\
\hline D8 & 48.87 & 38.32 & 12.81 & Loam \\
\hline D9 & 62.88 & 18.52 & 18.60 & Sandy loam \\
\hline D10 & 65.90 & 22.33 & 11.77 & Sandy loam \\
\hline D11 & 69.14 & 18.16 & 12.70 & Sandy loam \\
\hline
\end{tabular}

Table 5: Chemical parameters in earthen pond sediment at Delta Breeding Station after three months from stocking of fish

\begin{tabular}{|c|c|c|c|c|c|c|c|c|c|c|c|c|}
\hline Parameters & Con. & D1 & D2 & D3 & D4 & D5 & D6 & D7 & D8 & D9 & D10 & D11 \\
\hline PH & 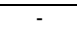 & 7.29 & 7.38 & 7.58 & 7.97 & 7.43 & 7.49 & 7.51 & 7.3 & 7.45 & 8.11 & 7.46 \\
\hline $\mathrm{CO}_{3}{ }^{2-}$ & $\mathrm{mg} \mathrm{kg}^{-1}$ & 0 & 0 & 0 & 0 & 0 & 0 & 0 & 0 & 0 & 0 & 0 \\
\hline $\mathrm{HCO}_{3}{ }^{-}$ & $\mathrm{mg} \mathrm{kg}^{-1}$ & 103.7 & 122 & 91.5 & 115.9 & 109.8 & 103.7 & 122 & 115.9 & 122 & 128.1 & 146.4 \\
\hline EC & $\mathrm{dS} \mathrm{m}^{-1}$ & 0.593 & 0.586 & 0.459 & 0.573 & 0.563 & 0.555 & 0.576 & 0.58 & 0.59 & 0.575 & 0.711 \\
\hline $\mathrm{Ca}^{2+}$ & $\mathrm{mg} \mathrm{kg}^{-1}$ & 42 & 46 & 33.5 & 42 & 40 & 45 & 43 & 46 & 48 & 50 & 62 \\
\hline $\mathrm{K}^{+}$ & $\mathrm{mg} \mathrm{kg}^{-1}$ & 18.5 & 15.2 & 11.7 & 12.5 & 11.8 & 15 & 18 & 16 & 17 & 15 & 19 \\
\hline $\mathrm{Mg}^{2+}$ & $\mathrm{mg} \mathrm{kg}^{-1}$ & 18 & 18 & 13 & 17 & 14 & 13.2 & 15 & 14 & 14.5 & 13.5 & 15 \\
\hline $\mathrm{Na}^{+}$ & $\mathrm{mg} \mathrm{kg}^{-1}$ & 36 & 33.5 & 26 & 33 & 38 & 29 & 33 & 34 & 34 & 31 & 39 \\
\hline $\mathrm{Cl}^{-}$ & $\mathrm{mg} \mathrm{kg}^{-1}$ & 88.8 & 78.1 & 60.4 & 81.7 & 85.2 & 80 & 81.7 & 88 & 81.7 & 71.5 & 99.4 \\
\hline $\mathrm{NO}_{2}^{-}$ & $\mathrm{mg} \mathrm{kg}^{-1}$ & 0.24 & 0.23 & 0.23 & 0.32 & 0.45 & 0.44 & 0.28 & 0.27 & 0.23 & 0.21 & 0.25 \\
\hline $\mathrm{NO}_{3}^{-}$ & $\mathrm{mg} \mathrm{kg}^{-1}$ & 7.5 & 12.4 & 12.5 & 14.5 & 13.9 & 14.5 & 12.4 & 9.7 & 7.7 & 7.9 & 11.2 \\
\hline $\mathrm{NH}_{4}-\mathrm{H}^{+}$ & $\mathrm{mg} \mathrm{kg}^{-1}$ & 5.5 & 6.8 & 7.6 & 8.7 & 9.5 & 10.5 & 8.8 & 8.4 & 6.6 & 7.2 & 10.9 \\
\hline $\mathrm{PO}_{4}{ }^{3-}$ & $\mathrm{mg} \mathrm{kg}^{-1}$ & 3.5 & 3.8 & 4.2 & 5.8 & 7.1 & 7.9 & 6.9 & 7.5 & 6.8 & 6.9 & 9.9 \\
\hline $\mathrm{SO}_{4}{ }^{2-}$ & $\mathrm{mg} \mathrm{kg}^{-1}$ & 68.5 & 62.5 & 47.5 & 51 & 44 & 50.5 & 47.5 & 47 & 58.5 & 60 & 65 \\
\hline Al & $\mathrm{mg} \mathrm{kg}^{-1}$ & 58420 & 51440 & 42330 & 46900 & 55240 & 46430 & 58080 & 61250 & 59980 & 48720 & 52490 \\
\hline As & $\mathrm{mg} \mathrm{kg}^{-1}$ & 0 & 0 & 0 & 0 & 0 & 0 & 0 & 0 & 0 & 0 & 0 \\
\hline $\mathrm{Ba}$ & $\mathrm{mg} \mathrm{kg}^{-1}$ & 336 & 247 & 410 & 401 & 456 & 408 & 450 & 470 & 438 & 380 & 384 \\
\hline Cd & $\mathrm{mg} \mathrm{kg}^{-1}$ & 3 & 4 & 3 & 2 & 4 & 3 & 6 & 8 & 5 & 7 & 8 \\
\hline Co & $\mathrm{mg} \mathrm{kg}^{-1}$ & 27 & 24 & 21 & 23 & 27 & 22 & 58 & 75 & 27 & 23 & 15 \\
\hline $\mathrm{Cr}$ & $\mathrm{mg} \mathrm{kg}^{-1}$ & 98 & 100 & 90 & 97 & 117 & 96 & 178 & 215 & 122 & 102 & 95 \\
\hline $\mathrm{Cu}$ & $\mathrm{mg} \mathrm{kg}^{-1}$ & 158 & 195 & 122 & 116 & 179 & 143 & 203 & 151 & 187 & 121 & 130 \\
\hline $\mathrm{Fe}$ & $\mathrm{mg} \mathrm{kg}^{-1}$ & 56880 & 53000 & 44640 & 48560 & 56360 & 45400 & 58870 & 57870 & 50750 & 47910 & 40040 \\
\hline Mn & $\mathrm{mg} \mathrm{kg}^{-1}$ & 439 & 440 & 453 & 692 & 519 & 527 & 640 & 700 & 632 & 693 & 633 \\
\hline Mo & $\mathrm{mg} \mathrm{kg}^{-1}$ & 0 & 0 & 0 & 0 & 0 & 0 & 0 & $\Omega$ & 0 & 0 & 0 \\
\hline $\mathrm{Ni}$ & $\mathrm{mg} \mathrm{kg}^{-1}$ & 0 & 0 & 0 & 0 & 0 & 0 & 0 & 0 & 0 & 0 & 0 \\
\hline $\mathrm{Pb}$ & $\mathrm{mg} \mathrm{kg}^{-1}$ & 14 & 17 & 11 & 37 & 16 & 14 & 22 & 30 & 13 & 15 & 8 \\
\hline Sb & $\mathrm{mg} \mathrm{kg}^{-1}$ & 0 & 0 & 0 & 0 & 0 & 0 & 0 & 0 & 0 & 0 & 0 \\
\hline $\mathrm{Se}$ & $\mathrm{mg} \mathrm{kg}^{-1}$ & 0 & 0 & 0 & 0 & 0 & 0 & 0 & 0 & 0 & 0 & 0 \\
\hline $\mathrm{V}$ & $\mathrm{mg} \mathrm{kg}^{-}$ & 401 & 486 & 378 & 581 & 502 & 429 & 1619 & 1634 & 554 & 485 & 582 \\
\hline $\mathrm{Zn}$ & $\mathrm{mg} \mathrm{kg}^{-1}$ & 157 & 166 & 124 & 140 & 142 & 116 & 475 & 478 & 120 & 115 & 108 \\
\hline $0 . M$ & $\mathrm{~g} \mathrm{~kg}^{2}$ & 16.9 & 20.1 & 16.9 & 16.9 & 20.1 & 13.2 & 16.9 & 22.1 & 16.9 & 22.1 & 32.1 \\
\hline
\end{tabular}


Table 6: Chemical parameters in earthen pond sediment at Delta Breeding Station after six months from stocking of fish

\begin{tabular}{|c|c|c|c|c|c|c|c|c|c|c|c|c|}
\hline Parameters & Con. & D1 & D2 & D3 & D4 & D5 & D6 & D7 & D8 & D9 & D10 & D11 \\
\hline PH & - & 7.4 & 7.5 & 7.4 & 7.6 & 6.8 & 7.1 & 7.3 & 7.2 & 7.3 & 7.21 & 7.01 \\
\hline $\mathrm{CO}_{3}{ }^{2-}$ & $\mathrm{mg} \mathrm{kg}^{-1}$ & 0 & 0 & 0 & 0 & 0 & 0 & 0 & 0 & 0 & 0 & 0 \\
\hline $\mathrm{HCO}_{3}^{-}$ & $\mathrm{mg} \mathrm{kg}^{-1}$ & 122 & 128.1 & 152.5 & 122 & 134.2 & 109.8 & 134.2 & 140.3 & 122 & 128.1 & 152.5 \\
\hline EC & $\mathrm{dS} \mathrm{m}^{-1}$ & 0.695 & 0.706 & 0.693 & 0.606 & 0.655 & 0.601 & 0.66 & 0.695 & 0.626 & 0.601 & 0.855 \\
\hline $\mathrm{Ca}^{2+}$ & $\mathrm{mg} \mathrm{kg}^{-1}$ & 46 & 51 & 40 & 42 & 43 & 47 & 48 & 49 & 49 & 50 & 65 \\
\hline $\mathrm{K}^{+}$ & $\mathrm{mg} \mathrm{kg}^{-1}$ & 22 & 21 & 24 & 15 & 14 & 16 & 20 & 19 & 17.5 & 16 & 27 \\
\hline $\mathrm{Mg}^{2+}$ & $\mathrm{mg} \mathrm{kg}^{-1}$ & 21.5 & 21 & 21 & 18 & 18 & 14.7 & 18 & 20 & 15.5 & 14 & 22 \\
\hline $\mathrm{Na}^{+}$ & $\mathrm{mg} \mathrm{kg}^{-1}$ & 44 & 39 & 47 & 35 & 43 & 33 & 38 & 41 & 36 & 34 & 48 \\
\hline $\mathrm{Cl}^{-}$ & $\mathrm{mg} \mathrm{kg}^{-1}$ & 98 & 99.5 & 88.7 & 88 & 96 & 88.7 & 95.8 & 106.5 & 88.7 & 77.6 & 133.1 \\
\hline $\mathrm{NO}_{2}^{-}$ & $\mathrm{mg} \mathrm{kg}^{-1}$ & 0.27 & 0.27 & 0.28 & 0.25 & 0.28 & 0.28 & 0.32 & 0.34 & 0.35 & 0.31 & 0.31 \\
\hline $\mathrm{NO}_{3}^{-}$ & $\mathrm{mg} \mathrm{kg}^{-1}$ & 8.5 & 13.4 & 14.8 & 15.5 & 15.6 & 16.5 & 16.5 & 12.2 & 11.9 & 8.1 & 15.6 \\
\hline $\mathrm{NH}_{4}-\mathrm{H}^{+}$ & $\mathrm{mg} \mathrm{kg}^{-1}$ & 7.1 & 9.5 & 9.6 & 10.4 & 12.5 & 11.1 & 9.9 & 10.5 & 9.3 & 8.5 & 12.5 \\
\hline $\mathrm{PO}_{4}{ }^{3-}$ & $\mathrm{mg} \mathrm{kg}^{-1}$ & 4.9 & 7.7 & 7.5 & 6.2 & 9.8 & 8.2 & 7.7 & 8.8 & 7.9 & 7.2 & 11.1 \\
\hline $\mathrm{SO}_{4}{ }^{2-}$ & $\mathrm{mg} \mathrm{kg}^{-1}$ & 87 & 78 & 67 & 52 & 47 & 54 & 54 & 52 & 60 & 63 & 76 \\
\hline $\mathrm{Al}$ & $\mathrm{mg} \mathrm{kg}^{-1}$ & 49240 & 46110 & 45390 & 41220 & 47830 & 44530 & 57750 & 61560 & 54350 & 56790 & 52750 \\
\hline As & $\mathrm{mg} \mathrm{kg}^{-1}$ & 0 & 0 & 0 & 0 & 0 & 0 & 0 & 0 & 0 & 0 & 0 \\
\hline $\mathrm{Ba}$ & $\mathrm{mg} \mathrm{kg}^{-1}$ & 379 & 374 & 441 & 458 & 363 & 428 & 470 & 470 & 522 & 536 & 507 \\
\hline Cd & $\mathrm{mg} \mathrm{kg}^{-1}$ & 5 & 5 & 5 & 6 & 5 & 5 & 5 & 5 & 6 & 8 & 11 \\
\hline Co & $\mathrm{mg} \mathrm{kg}^{-1}$ & 37 & 39 & 37 & 34 & 57 & 37 & 73 & 83 & 31 & 44 & 41 \\
\hline $\mathrm{Cr}$ & $\mathrm{mg} \mathrm{kg}^{-1}$ & 106 & 109 & 108 & 90 & 127 & 94 & 260 & 390 & 119 & 114 & 122 \\
\hline $\mathrm{Cu}$ & $\mathrm{mg} \mathrm{kg}^{-1}$ & 200 & 219 & 159 & 184 & 187 & 150 & 210 & 143 & 142 & 272 & 312 \\
\hline $\mathrm{Fe}$ & $\mathrm{mg} \mathrm{kg}^{-1}$ & 54830 & 56560 & 54420 & 48680 & 55600 & 54120 & 57210 & 62230 & 61450 & 65700 & 67250 \\
\hline Mn & $\mathrm{mg} \mathrm{kg}^{-1}$ & 578 & 655 & 557 & 573 & 530 & 635 & 661 & 694 & 652 & 955 & 1170 \\
\hline Mo & $\mathrm{mg} \mathrm{kg}^{-1}$ & 0 & 0 & 0 & 0 & 0 & 0 & 0 & 0 & 0 & 0 & 0 \\
\hline $\mathrm{Ni}$ & $\mathrm{mg} \mathrm{kg}^{-1}$ & 89 & 83 & 85 & 72 & 97 & 84 & 76 & 88 & 86 & 89 & 94 \\
\hline $\mathrm{Pb}$ & $\mathrm{mg} \mathrm{kg}^{-1}$ & 21 & 32 & 35 & 44 & 29 & 27 & 43 & 55 & 41 & 38 & 49 \\
\hline $\mathrm{Sb}$ & $\mathrm{mg} \mathrm{kg}^{-1}$ & 0 & 0 & 0 & 0 & 0 & 0 & 0 & 0 & 0 & 0 & 0 \\
\hline Se & $\mathrm{mg} \mathrm{kg}^{-1}$ & 0 & 0 & 0 & 0 & 0 & 0 & 0 & 0 & 0 & 0 & 0 \\
\hline V & $\mathrm{mg} \mathrm{kg}^{-1}$ & 422 & 485 & 401 & 585 & 508 & 433 & 1639 & 1657 & 585 & 492 & 612 \\
\hline Zn & $\mathrm{mg} \mathrm{kg}^{-1}$ & 243 & 261 & 311 & 275 & 273 & 335 & 522 & 511 & 261 & 676 & 825 \\
\hline O.M & $\mathrm{g} \mathrm{kg}^{-1}$ & 20.1 & 22.3 & 27.5 & 22.1 & 24.5 & 16.9 & 20.1 & 27.5 & 28.5 & 26.9 & 40.2 \\
\hline
\end{tabular}

The Hierarchical Cluster Analysis Figure 2 indicates that the sediments of the earthen ponds, after 3 months from the stocking of the grass carp could be clustered into two main groups basing on the parameters of sediment in each pond:

The first group contained the earthen ponds (D7 and D8) which were stocked with breeders of grass carp. The sediments in those ponds revealed the greater values. The second group was divided into two subgroups; the first one contained the sediments of the earthen ponds (D1, D2 \& D5) and the second is sediments of earthen pond (D9). Those earthen ponds were also stocked with fingerlings of grass carp and their sediment contents revealed moderate total content of parameters especially trace metals. Concerning the other subgroup which was stocked with the fingerlings of grass carp, it revealed the smallest physico-chemical values. This group was divided into two subgroups. The first group contained the earthen pond (D11) while the second group contained the earthen ponds (D4), (D10), (D6) and (D3) as shown in Figure 2. 
Table (7) Chemical parameters in earthen pond sediment at Delta Breeding Station after nine months from stocking of fish

\begin{tabular}{|c|c|c|c|c|c|c|c|c|c|c|c|c|}
\hline $\begin{array}{l}\text { Parameter } \\
\text { s }\end{array}$ & Con. & D1 & D2 & D3 & D4 & D5 & D6 & D7 & D8 & D9 & D10 & D11 \\
\hline PH & - & 6.1 & 6.82 & 6.83 & 6.48 & 6.79 & 6.67 & 6.5 & 6.79 & 7.16 & 6.5 & 6.79 \\
\hline $\mathrm{CO}_{3}{ }^{2-}$ & $\mathrm{mg} \mathrm{kg}^{-1}$ & 0 & 0 & 0 & 0 & 0 & 0 & 0 & 0 & 0 & 0 & 0 \\
\hline $\mathrm{HCO}_{3}^{-}$ & $\mathrm{mg} \mathrm{kg}^{-1}$ & 152.5 & 134.2 & 152.5 & 134.2 & 152.5 & 115.9 & 134.2 & 146.4 & 134.2 & 152.7 & 158.6 \\
\hline EC & $\mathrm{dS} \mathrm{m}^{-1}$ & 0.84 & 0.727 & 0.697 & 0.703 & 0.875 & 0.613 & 0.757 & 0.788 & \begin{tabular}{|l|}
0.752 \\
\end{tabular} & 0.705 & 0.926 \\
\hline $\mathrm{Ca}^{2+}$ & $\mathrm{mg} \mathrm{kg}^{-1}$ & 55 & 52 & 40 & 45 & 51 & 48 & 52 & 54 & 55 & 53 & 68 \\
\hline $\mathrm{K}^{+}$ & $\mathrm{mg} \mathrm{kg}^{-1}$ & 29 & 22 & 24.5 & 19 & 26 & 15.5 & 23 & 27 & 21 & 23 & 29 \\
\hline $\mathrm{Mg}^{2+}$ & $\mathrm{mg} \mathrm{kg}^{-1}$ & 27 & 21.5 & 21.2 & 21 & 27 & 15.2 & 22 & 23 & 19.5 & 18 & 27 \\
\hline $\mathrm{Na}^{+}$ & $\mathrm{mg} \mathrm{kg}^{-1}$ & 48 & 43 & 48 & 45 & 57 & 35 & 42 & 44 & 45 & 41 & 50 \\
\hline $\mathrm{Cl}^{-}$ & $\mathrm{mg} \mathrm{kg}^{-1}$ & 116 & 103.1 & 88.7 & 103.1 & 133.1 & 88.7 & 121 & 133.1 & \begin{tabular}{|l|}
106.5 \\
\end{tabular} & 88.8 & 146.2 \\
\hline $\mathrm{NO}_{2}^{-}$ & $\mathrm{mg} \mathrm{kg}^{-1}$ & 0.32 & 0.34 & 0.32 & 0.3 & 0.33 & 0.34 & 0.37 & 0.4 & 0.39 & 0.38 & 0.38 \\
\hline $\mathrm{NO}_{3}^{-}$ & $\mathrm{mg} \mathrm{kg}^{-1}$ & 15.8 & 12.5 & 14.9 & 15.9 & 17.1 & 15.2 & 20.2 & 13.5 & 17.5 & 10.5 & 15.9 \\
\hline $\mathrm{NH}_{4}-\mathrm{H}^{+}$ & $\mathrm{mg} \mathrm{kg}^{-1}$ & 10.2 & 8.4 & 9.2 & 11 & 14.6 & 10.2 & 12.9 & 12.1 & 12.1 & 9.8 & 13 \\
\hline $\mathrm{PO}_{4}{ }^{3-}$ & $\mathrm{mg} \mathrm{kg}^{-1}$ & 7.9 & 6.4 & 7.6 & 7.5 & 13.1 & 8.3 & 10.2 & 10.5 & 9.1 & 8.7 & 11.5 \\
\hline $\mathrm{SO}_{4}{ }^{2-}$ & $\mathrm{mg} \mathrm{kg}^{-1}$ & 99 & 82 & 69 & 65 & 82 & 56 & 58 & 53 & 80 & 73 & 88 \\
\hline Al & $\mathrm{mg} \mathrm{kg}^{-1}$ & 49160 & 52550 & 46090 & 44040 & 48640 & 46420 & 57840 & 61990 & 58370 & 50900 & 53700 \\
\hline As & $\mathrm{mg} \mathrm{kg}^{-1}$ & 0 & 0 & 0 & 0 & 0 & \begin{tabular}{|c|} 
T \\
\end{tabular} & 0 & \begin{tabular}{|l|}
0 \\
\end{tabular} & \begin{tabular}{|c|}
0 \\
\end{tabular} & 0 & \begin{tabular}{|l}
0 \\
0
\end{tabular} \\
\hline $\mathbf{B a}$ & $\mathrm{mg} \mathrm{kg}^{-1}$ & 440 & 470 & 510 & 590 & 540 & 670 & 440 & 490 & 540 & 547 & 600 \\
\hline Cd & $\mathrm{mg} \mathrm{kg}^{-1}$ & 9 & 10 & 7 & 7 & 8 & 6 & 9 & 10 & 11 & 15 & 12 \\
\hline Co & $\mathrm{mg} \mathrm{kg}^{-1}$ & 50 & 38 & 40 & 37 & 59 & 35 & 75 & 81 & 42 & 47 & 39 \\
\hline $\mathrm{Cr}$ & $\mathrm{mg} \mathrm{kg}^{-1}$ & 110 & 105 & 116 & 99 & 122 & 96 & 378 & 415 & 125 & 110 & 120 \\
\hline $\mathrm{Cu}$ & $\mathrm{mg} \mathrm{kg}^{-1}$ & 254 & 205 & 158 & 196 & 196 & 160 & 355 & 396 & 150 & 333 & 355 \\
\hline $\mathrm{Fe}$ & $\mathrm{mg} \mathrm{kg}^{-1}$ & 58240 & 54610 & 55330 & 56710 & 58680 & 60870 & 80400 & 81160 & 57609 & 67950 & 68890 \\
\hline Mn & $\mathrm{mg} \mathrm{kg}^{-1}$ & 640 & 630 & 660 & 700 & 620 & 740 & 928 & 1282 & 730 & 990 & 1200 \\
\hline Mo & $\mathrm{mg} \mathrm{kg}^{-1}$ & 0 & 0 & 0 & 0 & 0 & 0 & 0 & 0 & 0 & 0 & 0 \\
\hline $\mathrm{Ni}$ & $\mathrm{mg} \mathrm{kg}^{-1}$ & 98 & 92 & 101 & 98 & 106 & 108 & 109 & 103 & 111 & 112 & 101 \\
\hline $\mathrm{Pb}$ & $\mathrm{mg} \mathrm{kg}^{-1}$ & 26 & 48 & 34 & 46 & 34 & 31 & 47 & 57 & 52 & 43 & 53 \\
\hline $\mathrm{Sb}$ & $\mathrm{mg} \mathrm{kg}^{-1}$ & 0 & 0 & 0 & 0 & 0 & 0 & 0 & 0 & 0 & 0 & 0 \\
\hline Se & $\mathrm{mg} \mathrm{kg}^{-1}$ & 0 & 0 & 0 & 0 & 0 & 0 & 0 & 0 & 0 & 0 & 0 \\
\hline V & $\mathrm{mg} \mathrm{kg}^{-1}$ & 429 & 503 & 414 & 603 & 515 & 445 & 1680 & 1705 & 599 & 485 & 605 \\
\hline $\mathrm{Zn}$ & $\mathrm{mg} \mathrm{kg}^{-1}$ & 247 & 294 & 313 & 371 & 268 & 407 & 585 & 595 & 319 & 701 & 753 \\
\hline O.M & $\mathrm{g} \mathrm{kg}^{-1}$ & 26.9 & 27.5 & 29.5 & 28.5 & 42.5 & 26.9 & 29.5 & 31.5 & 32.2 & 42.7 & 50.2 \\
\hline
\end{tabular}

Dendrogram using Average Linkage (Between Groupa)

Rescaled Distance Cluster Combine
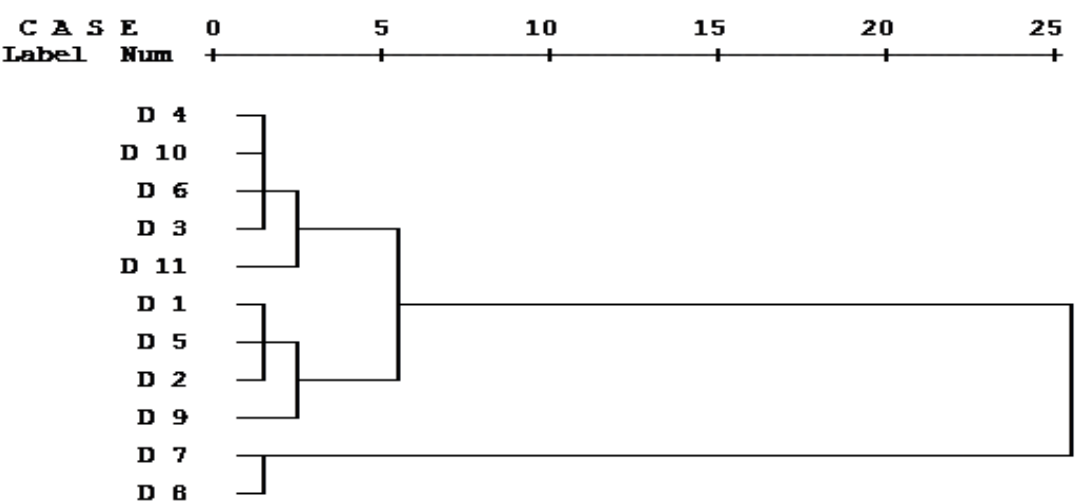

Figure 2: Hierarchical Cluster Analysis showing the linkage between different earthen ponds basing on the chemical parameters of the sediments after three months from the stocking of the fish 
After 6 months from stocking the ponds with the fish of grass carp, the Hierarchical Cluster Analysis (Figure, 4) indicated that the quality of the sediments could be clustered into two main groups:

The first group contained the earthen ponds (D7 \& D8) which were stocked with breeders of grass carp. The sediment of those earthen ponds revealed the greater physico-chemical values. Concerning the other group, it was divided into two subgroups. The first subgroup contained the earthen ponds D9, D10 and D11 which revealed moderate total content of parameters especially trace metals. The second subgroup was divided into two sub-sub groups, the first one contained the earthen pond (D4) while, the second group contained the earthen ponds (D3), (D6), (D2) (D1) and (D5) in which, the sediments had the smallest physico-chemical values, as shown in Figure 3.

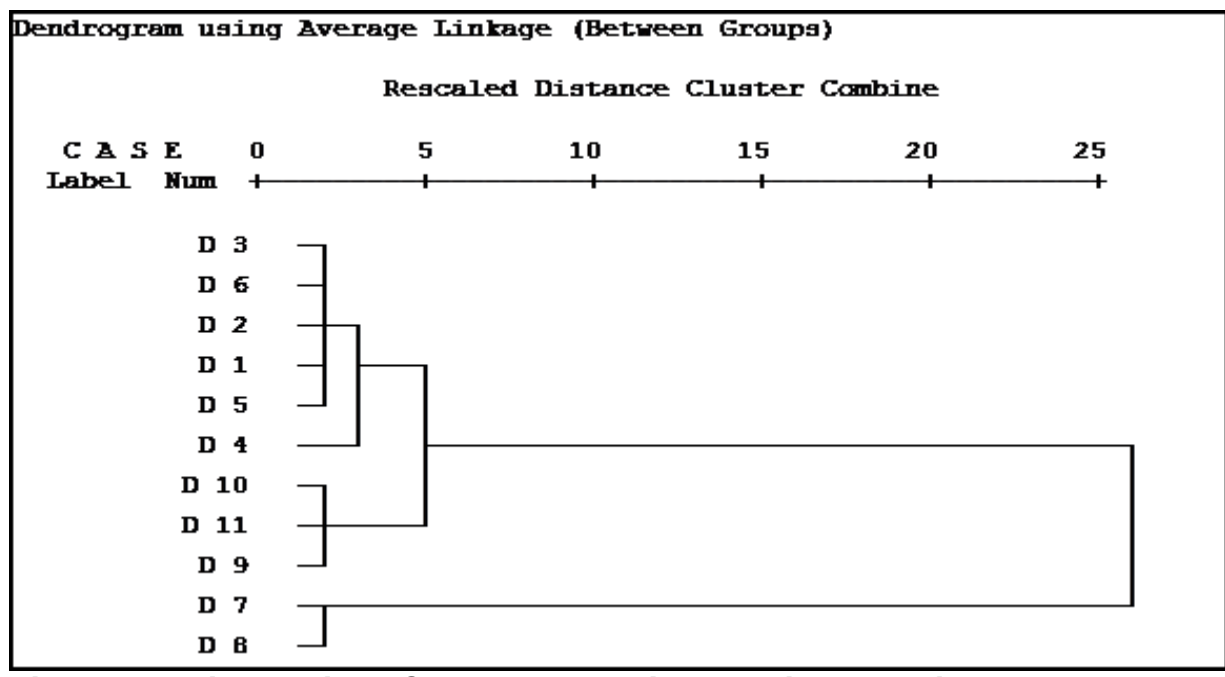

Figure 3: Hierarchical Cluster Analysis showing the linkage between different earthen ponds basing on the chemical parameters of the sediment after sex months from the stocking of the fish

After nine months from stocking the earthen ponds with the grass carp, the Hierarchical Cluster Analysis (Figure, 4) indicated that the sediments within the earthen ponds could be clustered into two main groups: The first group contained the earthen ponds (D7 \& D8) which were stocked with breeders of grass carp. There earthen ponds revealed the greater chemical values. Concerning the second group it was divided into two subgroups. The first subgroup contained (D2), (D11) and (D9). These earthen ponds were stocked with fingerlings of grass carp and their sediments revealed moderate values of physico-chemical parameters especially trace metals. The second subgroup contained the earthen ponds (D1), (D5), (D10), (D6), (D3) and (D4). The sediments of this group was characterized by the smallest chemical values as compared with the other groups as shown in Figure 4. 
Based on the cluster groups, the present study indicated that it is impossible to distinguish a general pattern or even similarity among the sediments within the earthen ponds. But, it is clear that the sediments in earthen ponds which were stocked by the breeders of grass carp are usually characterized by higher values of chemical parameters more than the sediments of the earthen ponds which were stocked with fingerlings of grass carp. This is properly due to the feeding processes (uneaten, decaying food and food consumption). Yuan, (2012) stated that the feeding habit of fish induces accumulation of waste at pond bottom, which causes heterotrophic bacteria breeding and leads to hypoxia (lack of dissolved oxygen), nitrite and nitrogen enrich. Oxygen deficiency causes pathogenic bacteria (e.g. vibrio) breeding and decreases cultured fish immunity ability; in that case, it is easy to happen disease. Sediment is seedbed of many pathogenic bacteria, remove excess slit at bottom, or introduce beneficial microorganisms to decompose waste.

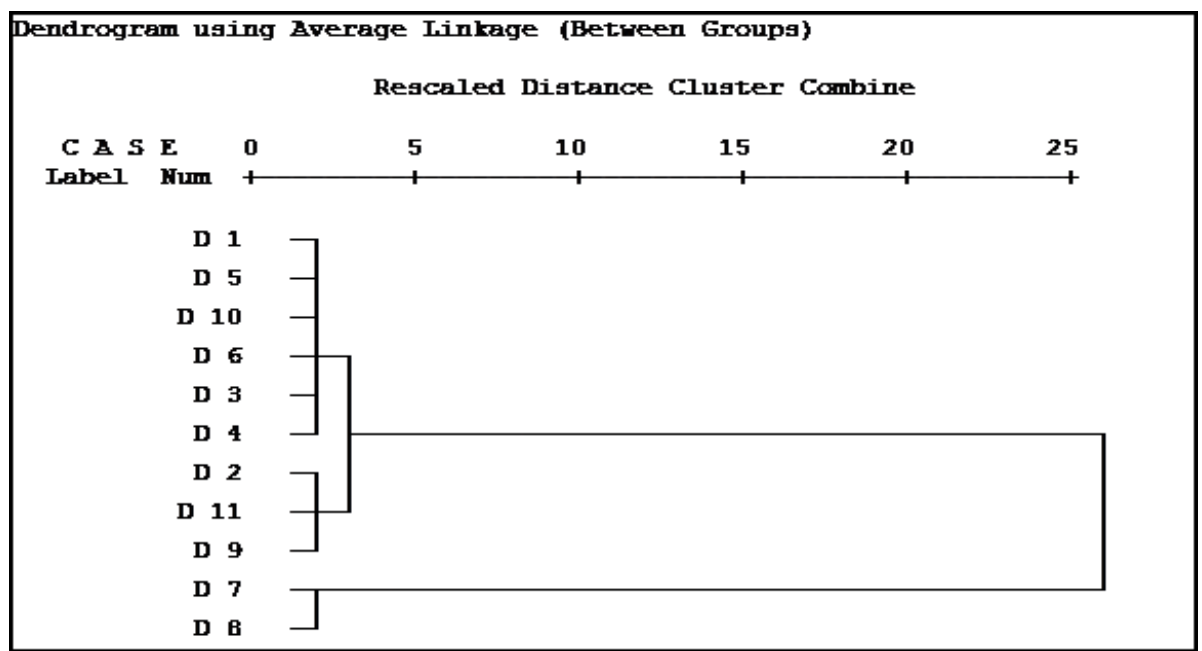

Figure 4: Hierarchical Cluster Analysis showing the linkage between different earthen ponds basing on the chemical parameters of the sediment after nine months from the stocking of the fish

The ponds which were used for rearing the fry were fertilized for proliferation of natural feed organisms and then were provided with supplemental artificial feeds at fingerlings stages, all grass carp feed on the same type of food with diet composition containing fish-meal (20-30\%), soya meal $(15 \%)$ and sorghum $(20 \%)$, minerals and heavy metals as shown in Table 3 which are essential elements for fish body composition. So, the Hierarchical Cluster Analysis showed that sediments in earthen ponds that were used for rearing fry and fingerlings of grass carp were quite similar due to the similar structure of feeding, but, when the diet composition (clover) changes as fish grow (breeder) the quality of the sediments dramatically change. 
To obtain more reliable information about the sediment quality in the earthen ponds at (DBS) after 3, 6 and 9 months from the stocking of fish and to identify problems raised from different activities in the fish farm especially that cause sediment pollution, the physical and chemical parameters were evaluated after 3, 6 and 9 months from the fish stocking by using the statistical analysis (t test). The results presented in Table 8 showed that sediment absorbed heavy metals and some nutrients from different inputs and it had a tendency to accumulate trace metals and some nutrients.

Table 8: Mean values of chemical parameters within the sediments of the earthen ponds at Delta Breeding Station after 3, 6 and 9 months from the stocking of fish and their Std. error and the significant variation among them

\begin{tabular}{|c|c|c|c|c|c|c|c|c|c|c|}
\hline \multirow{2}{*}{$\begin{array}{l}\text { Physico-chemical } \\
\text { parameters }\end{array}$} & \multirow[b]{2}{*}{ df } & \multirow[b]{2}{*}{\begin{tabular}{|c|} 
After 3 \\
months
\end{tabular}} & \multicolumn{2}{|c|}{ Mean } & \multirow[b]{2}{*}{$\begin{array}{c}\text { After } 3 \\
\text { months }\end{array}$} & \multirow{2}{*}{\begin{tabular}{|c} 
Std. Error \\
After 6 \\
months
\end{tabular}} & \multirow[b]{2}{*}{$\begin{array}{c}\text { After } 9 \\
\text { months }\end{array}$} & \multicolumn{3}{|c|}{ P-value (2-tailed) } \\
\hline & & & $\begin{array}{c}\text { After } 6 \\
\text { months }\end{array}$ & $\begin{array}{l}\text { After } 9 \\
\text { months }\end{array}$ & & & & $(3-6)$ & $(3-9)$ & $(6-9)$ \\
\hline $\mathrm{PH}$ & 10 & 7.5427 & 7.2564 & 6.6755 & .07903 & .06884 & .08257 & 0.010 & 0.000 & 0.001 \\
\hline$\left(\mathrm{mg} \mathrm{kg}^{-1}\right)$ & 10 & $a$ & $a$ & $\mathrm{a}$ & $a$ & $a$ & $a$ & $a$ & $a$ & $a$ \\
\hline$\left(\mathrm{mg} \mathrm{kg}^{-1}\right)$ & 10 & \begin{tabular}{|l|}
116.4545 \\
\end{tabular} & 131.4273 & 142.5364 & 4.3875 & 3.9757 & 3.8865 & 0.018 & 0.001 & 0.004 \\
\hline$\left(\mathrm{dS} \mathrm{m}^{-1}\right)$ & 10 & 0.5783 & 0.6721 & 0.7621 & 0.0173 & 0.0219 & 0.0271 & 0.000 & 0.000 & 0.001 \\
\hline$\left(\mathrm{mg} \mathrm{kg}^{-1}\right)$ & 10 & 45.2273 & 48.1818 & 52.0909 & 2.1398 & 1.9854 & 2.1082 & 0.001 & 0.000 & 0.004 \\
\hline$\left(\mathrm{mg} \mathrm{kg}^{-1}\right)$ & 10 & 15.4273 & 19.2273 & 23.5455 & 0.7843 & 1.2198 & 1.2549 & 0.006 & 0.000 & 0.004 \\
\hline$\left(\mathrm{mg} \mathrm{kg}^{-1}\right)$ & 10 & 15.0182 & 18.5182 & 22.0364 & 0.5538 & 0.8551 & 1.1535 & 0.001 & 0.000 & 0.001 \\
\hline$\left(\mathrm{mg} \mathrm{kg}^{-1}\right)$ & 10 & 33.3182 & 39.8182 & 45.2727 & 1.1287 & 1.5656 & 1.6954 & 0.002 & 0.000 & 0.001 \\
\hline$\left(\mathrm{mg} \mathrm{kg}^{-1}\right)$ & 10 & 81.5000 & 96.4182 & \begin{tabular}{|l|}
111.6636 \\
\end{tabular} & 2.9981 & 4.3311 & 6.0064 & 0.000 & 0.000 & 0.001 \\
\hline$\left(\mathrm{mg} \mathrm{kg}^{-1}\right)$ & 10 & 0.2864 & 0.2964 & 0.3518 & 0.0253 & 0.0956 & 0.0101 & 0.744 & 0.056 & 0.000 \\
\hline$\left(\mathrm{mg} \mathrm{kg}^{-1}\right)$ & 10 & 11.2909 & 13.5091 & 15.3636 & 0.8125 & 0.9091 & 0.7822 & 0.000 & 0.002 & 0.046 \\
\hline \begin{tabular}{|l}
$\mathrm{NH}_{4}-\mathrm{H}^{+} \quad\left(\mathrm{mg} \mathrm{kg}^{-1}\right)$ \\
\end{tabular} & 10 & 8.2273 & 10.0818 & 11.2273 & 0.5052 & 0.4825 & 0.5652 & 0.000 & 0.000 & 0.033 \\
\hline$\left(\mathrm{mg} \mathrm{kg}^{-1}\right)$ & 10 & 6.3903 & 7.9091 & 9.1636 & 0.5817 & 0.4988 & 0.5971 & 0.002 & 0.000 & 0.013 \\
\hline$\left(\mathrm{mg} \mathrm{kg}^{-1}\right)$ & 10 & \begin{tabular}{|l|}
54.7273 \\
\end{tabular} & 62.7273 & 73.1818 & 2.5382 & 3.8778 & 4.3752 & 0.003 & 0.000 & 0.006 \\
\hline$\left(\mathrm{mg} \mathrm{kg}^{-1}\right)$ & 10 & \begin{tabular}{|l|}
52843.64 \\
\end{tabular} & \begin{tabular}{|l|}
50683.64 \\
\end{tabular} & \begin{tabular}{|l|}
51790.91 \\
\end{tabular} & \begin{tabular}{|l|}
1887.640 \\
\end{tabular} & 1930.201 & \begin{tabular}{|l|}
1724.649 \\
\end{tabular} & 0.189 & 0.389 & 0.258 \\
\hline$\left(\mathrm{mg} \mathrm{kg}^{-1}\right)$ & 10 & $a$ & $a$ & $a$ & $\mathrm{a}$ & $a$ & $\mathrm{a}$ & $a$ & $a$ & $\mathrm{a}$ \\
\hline$\left(\mathrm{mg} \mathrm{kg}^{-1}\right)$ & 10 & 398.1818 & 449.8182 & \begin{tabular}{|l|}
530.6364 \\
\end{tabular} & \begin{tabular}{|l|}
19.13342 \\
\end{tabular} & 18.00092 & \begin{tabular}{|l|}
21.4019 \\
\end{tabular} & 0.034 & 0.000 & 0.007 \\
\hline$\left(\mathrm{mg} \mathrm{kg}^{-1}\right)$ & 10 & 4.8181 & 6.0000 & 9.4545 & 0.6441 & 0.5721 & 0.7788 & 0.002 & 0.000 & 0.000 \\
\hline$\left(\mathrm{mg} \mathrm{kg}^{-1}\right)$ & 10 & 31.0909 & 46.6364 & \begin{tabular}{|l|}
49.3636 \\
\end{tabular} & 5.49951 & 5.13858 & 4.76211 & 0.000 & 0.000 & 0.104 \\
\hline$\left(\mathrm{mg} \mathrm{kg}^{-1}\right)$ & 10 & \begin{tabular}{|l|}
119.0909 \\
\end{tabular} & 149.0000 & \begin{tabular}{|l|}
163.2727 \\
\end{tabular} & \begin{tabular}{|l|}
12.1471 \\
\end{tabular} & 27.8593 & \begin{tabular}{|l|}
34.9646 \\
\end{tabular} & 0.095 & 0.088 & 0.211 \\
\hline$\left(\mathrm{mg} \mathrm{kg}^{-1}\right)$ & 10 & \begin{tabular}{|l|}
155.0000 \\
\end{tabular} & 198.0000 & \begin{tabular}{|l|}
250.7273 \\
\end{tabular} & 9.5051 & 16.3384 & \begin{tabular}{|l|}
27.7466 \\
\end{tabular} & 0.042 & 0.009 & 0.048 \\
\hline$\left(\mathrm{mg} \mathrm{kg}^{-1}\right)$ & 10 & \begin{tabular}{|l|}
50934.55 \\
\end{tabular} & 58004.55 & \begin{tabular}{|l|}
63677.18 \\
\end{tabular} & 1868.12 & 1673.01 & \begin{tabular}{|l|}
2908.29 \\
\end{tabular} & 0.028 & 0.001 & 0.048 \\
\hline$\left(\mathrm{mg} \mathrm{kg}^{-1}\right)$ & 10 & \begin{tabular}{|l|}
578.9091 \\
\end{tabular} & 696.3636 & \begin{tabular}{|l|}
829.0909 \\
\end{tabular} & 31.75945 & 58.48485 & 71.38238 & 0.050 & 0.001 & 0.025 \\
\hline$\left(\mathrm{mg} \mathrm{kg}^{-1}\right)$ & 10 & $a$ & $a$ & $a$ & $a$ & $a$ & $a$ & $a$ & $a$ & $a$ \\
\hline$\left(\mathrm{mg} \mathrm{kg}^{-1}\right)$ & 10 & 0.0000 & 85.7273 & \begin{tabular}{|l|}
103.5455 \\
\end{tabular} & 0.0000 & 2.16623 & 1.88469 & 0.000 & 0.000 & 0.000 \\
\hline$\left(\mathrm{mg} \mathrm{kg}^{-1}\right)$ & 10 & 17.9091 & 37.6364 & 42.8182 & 2.59529 & 3.03696 & 3.04756 & 0.000 & 0.000 & 0.004 \\
\hline$(\mathrm{mg} \mathrm{kg}$ & 10 & a & a & a & a & a & a & a & a & a \\
\hline$\left(\mathrm{mg} \mathrm{kg}^{\circ}\right.$ & 10 & a & a & a & a & a & a & a & a & a \\
\hline$\left(\mathrm{mg} \mathrm{kg}^{-1}\right)$ & 10 & \begin{tabular}{|l|}
695.5455 \\
\end{tabular} & 710.8182 & \begin{tabular}{|l}
725.7273 \\
\end{tabular} & \begin{tabular}{|l|}
140.2547 \\
\end{tabular} & 141.2542 & \begin{tabular}{|l|}
145.5803 \\
\end{tabular} & 0.001 & 0.001 & 0.016 \\
\hline$\left(\mathrm{mg} \mathrm{kg}^{-1}\right)$ & 10 & \begin{tabular}{|l|}
194.6364 \\
\end{tabular} & 408.4545 & 441.1818 & 42.3709 & 59.5750 & \begin{tabular}{|l|}
55.2591 \\
\end{tabular} & 0.009 & 0.002 & 0.050 \\
\hline$\left(\mathrm{g} \mathrm{kg}^{-1}\right)$ & 10 & 19.473 & 25.145 & 33.445 & 0.1496 & 0.1879 & 0.2393 & 0.000 & 0.000 & 0.000 \\
\hline
\end{tabular}

The fixation/mobilization potential of the sediment with respect to heavy metals is dependent on the $\mathrm{pH}$. The increase in $\mathrm{pH}$ in some locations promotes the precipitation of metals, which subsequently settle to the bottom of the earthen ponds and ultimately result in reduced water columns concentrations and perhaps increased concentrations of metals in sediments (Förstner and Wittmann, 1983). On the other hand, the decrease in the $\mathrm{pH}$ value may be attributed to the decomposition of descending plankton and 
organic matter which lead to the release of hydrogen sulfide and the formation of organic acids (Abdel-Satar, 2005).

The high percentage of organic matter within the sediment was mainly produced from waste product of protein metabolism by fish excretion, through the feeding system, dead plankton, and decaying aquatic weeds and fish. Such organic matter acts as a metal carrier and plays an important role in the metal distribution patterns within the sediment (Lin and Chen, 1998).

Intensive fish aquaculture can lead to higher proportion of organic materials and fertilizers such as ammonia, nitrate and phosphate compounds as well as the high proportion of heavy elements in the water and sediments (Madhav and Lin, 1996; Ali and Abdin, 2003; Bakry et al., 2004; Jawad et al., 2004; Ali et al., 2006; Tohamy et al., 2006 and El-Kholy, 2013). Similarly the present study show that during rearing of the grass carp of different sizes in the earthen ponds, the quality of the sediment has been changed with increasing the time. The values of $\mathrm{pH}$ have been statistically decreased. While the values of $(\mathrm{Ec}),\left(\mathrm{HCO}_{3}{ }^{-}\right),\left(\mathrm{Ca}^{2+}\right),\left(\mathrm{K}^{+}\right),\left(\mathrm{Mg}^{2+}\right),\left(\mathrm{Na}^{+}\right),(\mathrm{Cl}),\left(\mathrm{NO}_{2}^{-}\right)$, $\left(\mathrm{NO}_{3}{ }^{-}\right),\left(\mathrm{NH}_{4}-\mathrm{H}^{+}\right),\left(\mathrm{PO}_{4}{ }^{--}\right),\left(\mathrm{SO}_{4}{ }^{2-}\right)$ and the heavy metals $(\mathrm{Ba}),(\mathrm{Cd}),(\mathrm{Co}),(\mathrm{Cr})$, $(\mathrm{Cu}),(\mathrm{Fe}),(\mathrm{Mn}),(\mathrm{Ni}),(\mathrm{pb}),(\mathrm{V})$ and $(\mathrm{Zn})$ have been statistically increased as well as the percentage of organic matter (O.M \%).

Concerning the anions and cations in the sediment, the results show that most of their values attained the highest values, especially within the earthen ponds used for rearing the breeders of grass carp. The most predominant anions are chloride and sulfate. In case of the cations, the results show large variation in the cation contents however the highest values were achieved upon increasing the time of stocking of fish especially in earthen ponds stocked with breeders of grass carp. This result agrees with that stated by Abd El-Fattah (1994) who mentioned that both cations and anions increased with increasing the load of water pollutants.

In addition, the heavy metals in the earthen ponds whish were stocked with breeders were higher than those of those stocked with fry and fingerlings of grass carp. This result is mainly attributed to the feeding process and the organic matter percentages. Moreover, it is clear that the sediments act as a major sink for pollutants in the aquatic environment. Furthermore, it is clear that heavy metals accumulate in the sediments through complex chemical adsorption mechanisms depending on the nature of the sediment matrix and the properties of the adsorbed compounds (Maher and Aislabie, 1992). The adsorption process is influenced by several chemical parameters such as: $\mathrm{pH}$, oxidative-reductive potential, dissolved oxygen, organic and inorganic carbon content, and the presence of some anions and cations in water phase that can bind or co-precipitate the waterdissolved or suspended pollutants (Wen and Allen, 1999). The concentration of such metals in the water column can be relatively low, if it is compared with their concentrations in the sediment. Low-level discharges of a contaminant may meet the water quality criteria, but long-term partitioning to the sediment could result in the accumulation of high loads of pollutants (Binning and Baird, 2001). Therefore, the monitoring of accumulation of such trace metals in the sediment is fundamental to realized pollutant and its main cause. 
The present result showed that the mean concentrations of heavy metals in the water of the Nile River at El Kanater El-Kairia tended to be in the order of $\mathrm{Fe}>\mathrm{Mn}>\mathrm{Zn}>\mathrm{Pb}>\mathrm{Cu}>\mathrm{Ni}>\mathrm{Cd}$. Concerning the artificial diet, it had slightly the same order except for $\mathrm{Pb}(\mathrm{Fe}>\mathrm{Mn}>\mathrm{Zn}>\mathrm{Cu}>\mathrm{Ni}>\mathrm{Pb}>$ $\mathrm{Cd}$ ). Interestingly, in the polluted sediment, the order of abundance of the heavy metals followed the same trend like the artificial diet except for the sediment after 3 months from stocking of fish. The trend of the abundance of heavy metals was $\mathrm{Fe}>\mathrm{Mn}>\mathrm{Zn}>\mathrm{Cu}>\mathrm{Pb}>\mathrm{Cd}>\mathrm{Ni}$; $\mathrm{Fe}>\mathrm{Mn}>\mathrm{Zn}>\mathrm{Cu}>$ $\mathrm{Ni}>\mathrm{Pb}>\mathrm{Cd}$; and $\mathrm{Fe}>\mathrm{Mn}>\mathrm{Zn}>\mathrm{Cu}>\mathrm{Ni}>\mathrm{Pb}>\mathrm{Cd}$, after 3, 6 and 9 months from the stocking of fish, respectively. This suggests that the values of the heavy metals in the sediment are mainly attributed to the feeding process and the presence of organic matter which is oxide in the accumulation of the heavy metal to the sediment under oxic conditions. Also, it is clear that the ability of surface sediment in the earthen ponds to accumulate heavy metals from the water is variable and the mobilization of some chemical parameters from the sediment to water and vise versa is depending on some physical factors which include temperature and water turbulence.

Also, the high concentrations of the pollutants in the bottom sediment are considered indication for water content of those pollutants depending on the adsorption process which depends mainly on the grain size distribution of the bottom sediment and its chemical contents of the organic matter in association with intensive feeding process, consumption of food and deposition of fecal matter which represents the main cause of such pollutants. This statement coincides with the finding of Ali and Abdin (2003); MALR, (2003) and Ali et al. (2006) who found high concentration of organic matters and some heavy metal in the bottom sediment underneath the floating cages from feeds. Also, Tohamy et al. (2006) found high nutrient load in the sediment of earthen pond stocked with grass carp. Sundstrom et al. (1988) found that the sediment within the pond stocked with catfish (Ictalurus punctatus), contained relatively high levels of calcium ( $\mathrm{Ca}$ ) and magnesium $(\mathrm{Mg})$, and had a high base saturation percentage of phosphorus $(\mathrm{P})$, potassium $(\mathrm{K})$, copper $(\mathrm{Cu})$, zinc $(\mathrm{Zn})$ and manganese $(\mathrm{Mn})$ levels.

\section{Recommendations}

It is very important to provide good environmental condition to fish in order to have good result in nursery operation. Thus, pond preparation needs to be carried out before the stocking of fish in order to remove the pollutants from the sediment by using both natural and chemical treatments.

\section{REFERENCES}

Abd El-Fattah, R.I. (1994) Adaptive responses of Eichhornia crassipes (MART) Solms. to water pollution. Desert Inst. Bull., Egypt, 44(2):375389.

Abdel-Meguid, M. (1998). The frequency distrbution of Lernaea cyprinacea Linnaeus, 1761 (Copepoda:Cyclopoida) and its histopathological effect on the common carp, Cyprinus carpio. Egypt. J. Zool., 31:53-66. 
Abdel-Meguid, M. (1999). Histopathological lesions on the gill filaments of the common carp, Cyprinus carpio infected by the developmental stages of the copepod, Lernaea cyprinacea Lin., with special emphasis on their control. Egypt. J. Zool., 32:267-279.

Abdel-Meguid, M.; Abden, A; and Ali, M. M. (2005). Assess the efficiency of silver carp "Hypophthalmic molitrix", grass carp "Ctenopharyngodon idella" and common carp "Cyprinus carpio" at controlling the phytoplanktons. Engineering Research Journal, (97):C92-C109.

Abdel-Satar, A.M. (2005) Quality of River Nile sediments from Idfo to Cairo. Egyptian J. Of Aquatic Research, 31(2): 182-199.

Adriano, D.C. (2001) Trace elements in Terrestrial Environments: Biogeochemistry, bioavailability and Risks of Metals, $2^{\text {nd }}$ edn, Epringer, New York, $866 \mathrm{pp}$

Ali, M.M. and Abdin, A. E. (2003). Environmental impact of the surrounding conditions on the fish culture within floating cages in Damietta branch of the River Nile. J. Egypt. Acad. Soc. Environ. Develop. Vol. (4), No (3), pp. 37-60.

Ali, M.M.; Abdel-Meguid, M. ; and Abden, A. (2006). Assessment of floating fish cages impacts on the quality of water, sediment, aquatic weed, fish, fauna, flora and Hydraulics of Damietta Branch. Engineers Research Journal, 104:C91-C117.

American Public Health Association (APHA),(1998). Standard Methods of Examinations of Water and Wastewater.20th Edition, Washington, D.C.

Bakry, M.; Hosny, M.; and Abdel-Meguid, M. (2004). Effective control of nuisance submerged aquatic weed, Ceratophylum demersum in Aswan Reservoir by the herbivorous fish Ctenopharyngodon idella with special emphasis on its environmentalimpact.2nd Regional Conference on Arab Water 2004. Action Plans for Integrated Development.

Binning K. and Baird D. (2001) Survey of heavy metals in the sediments of the Swartkops River Estuary, Port Elizabeth South Africa, Water SA, 27 (4):461-466.

Boyd, C. E. (1971). The limnological role of aquatic macrophytes and their relationship to reservoir management. Am. Fish. Soc. Special Publication, 8:153-166.

Capone, D. G.; Weston, D. P.; Miler, V. and Shoemaker, V. C. (1996). Antibacterial residues in marine sediments and invertebrates following chemotherapy in aquaculture. Aquaculture 145: 55-75.

Carter, C. C. and Hestand, R. S. (1977). Relationship of regrowth of aquatic macrophytes after treatment with herbicides to waterquality and phytoplankton populations. J. Aquatic Plant Management, 15:65-69.

Chesapeake Bay Program (2006). Best Management Practices for Sediment Control and Water Clarity Enhancement. CBP/TRS-282-06.

El Atfy, H. and Abdel-Meguid, M. (2012). Fisheries and aquaculture in Egypt. International Training Workshop on Aquaculture. 21st June-7th July.

El-Kholy, R. (2013). Assessment of Fish Cages' Impacts on the Water Quality in Rosetta Branch of the Nile River Using Remote Sensing Technology. Nile Basin Water Science \& Engineering Journal, Vol.5, Issue 1, 2012. 
El Nemr, A., Khaled, A., \& Sikaily, A. E. (2006). Distribution and Statistical Analysis of Leachable and Total Heavy Metals in the Sediments of the Suez Gulf. Environmental Monitoring and Assessment, 118, 89-112.

Förstner, U. and Wittmann, G.T.W. (1983). Metal Pollution in the Aquatic Environment, Springer-Verlag, Berlin, Heidelberg, New York, 481 pp.

Gee, G.W. and J.W. Bauder. (1994). Particle-size Analysis. 377382-. In. Methods of Soil Analysis. Part 1, 3ed Edition. Physical and Mineralogical Methods. Edited by Klute, A. SSSA and ASA, Madison,WI.

Hektoen, H.; Berge, J. A.; , Hormazabal, V. and Yndestad, M. (1995). Persistence of antibacterial agents in marine sediments. Aquaculture 133: 175-184.

ILACO (1983). Grass carp project, Vouume 1-Main report, Code 5.09.091.

Jawad, K.; Mustapha, H.; Mohamed, D.; Mohamed, L. and Ahmed Y. (2004). Relation between phosphate and organic matter in fish-pond sediments of the Deroua fish farm (Béni-Mellal, Morocco): implications for pond management. Hydrobiologia, 450(1-3): 57-70.

Lin, J. and Chen, S. (1998) The Relationship between Adsorption of Heavy Metal and Organic Matter in River Sediment. Environment International, 24:345-352.

Madhav, K. S. and Lin, C. K. (1996). Phosphorus fertilization strategy in fish ponds based on sediment phosphorus saturation level. Aquaculture142 (3-4): 207-219.

Maher, W.A. and Aislabie, J. (1992). Polycyclic aromatic hydrocarbons in nearshore marine sediments of Australia. Sci. Total Environ. 11 (23):143-164.

MALR (2003). The environmental impact of fish farming in cages River Nile Damietta area - the first report - the summer season.

Nieboer, E. and Richardson, D.H. S. (1980). The replacement of the nondescript term Heavy metals by a biologically and chemically significant classification of metal ions. Environ. Pollution. 1: 3- 26.

Prowse, G.A. (1971). Experimental criteria for studying grass carp feeding in relation to weed control. The Progressive Fish-Culturist, 33:128-131.

Radojevic, M., \& Bashkin, V. N. (1999). Practical Environmental Analysis. Royal Society of Chemistry, Cambridge.

Recommended chemical soil test procedures (1998). North Central Regional Research Publication No. 221. Missouri Agricultural Experiment Station SB1001.

Sanita di Toppi, L. and Gabbrielli, R. (1999). Response to cadmium in higher plants. Environ. And Exper. Botany. 41: 105- 130.

Schriver, P.; Bogestrand, J.; Jeppesen, E. and Sondergaard, M. (1995). Impact of submerged macrophytes on fish-zooplankton-phytoplankton interactions: Large scale enclosure experiments in a shallow lake. Freswater Biol., 33:255-270.

Stanley, J. G. (1974). Nitrogen and phosphorous balance of grass carp, Ctenopharyngodon idella, fed elodea, Egeria densa. Trans. Am. Fish. Soc., 103:587-592. 
Sundstrom, F. J.; Sedberry, Jr.; and Avault, Jr. (1988). Feasibility of catfish pond sediment as a growing medium. Communications in Soil Science and Plant Analysis, 19:117 - 126.

Tohamy, M.; Abdel-Meguid, M.; and El-Bably, W. F. (2006). Maximization of economic and environmental benefits of area used in fish production. AQUA Tec, the 11th International Conference on Water Technology and Researches. 17-81. (In Arabic).

Von Donk, E.; Gulati, R. D.; ledema, A. J. and Meulemans, J. (1993). Macrophyte-related shifts in the nitrogen and phosphorus contents of the diiferent trophic levels in a biomanipulated shallow lake. Hydrobiologia, 251:19-26.

Wen, X. and Allen, H.E. (1999). Mobilization of heavy metals from Le An River sediments. Sci. Total Environ. 227:101-108.

Yuan Xinhua (2012). Fish Seed Nursing, in Reference Book for International Training Workshop on Aquaculture, Wuxi -China.

Zhou, Q.X., Kong, F.X. and Zho, L.; 2004, ecotoxicology. Sciencepress, Beijing, China (in Chinese).

تداعيات المزارع السمكية المائية على نوعيـة الرسوبيات داخل الأحواض الترابية

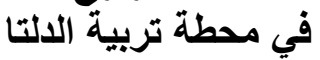

حسن حمزه عباس، عصمت حسن نوفل، محمد عبدالسلام عبدالمجيد، ياسر محمود علي،

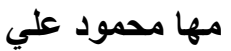

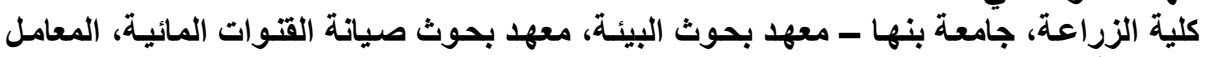
المركزية للرصد البيئي، المركز القومي لبحوثة المئية المياه.

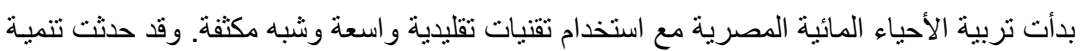

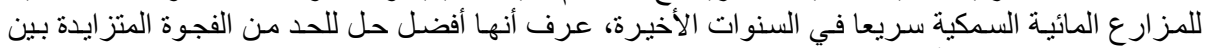

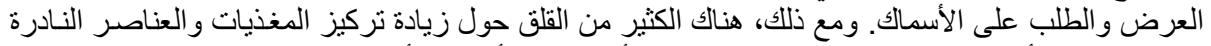

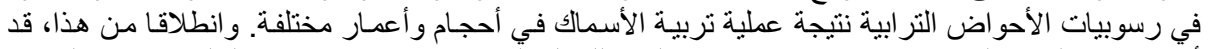

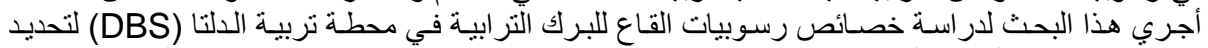

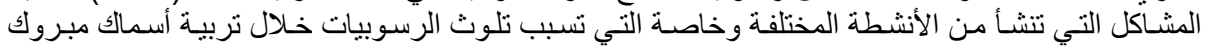

وقد أظهرت النتائج المنحصل عليها أن قو ام الرسوبيات في البرك الترابية متماثلا تقريباً حيث أنها الحثائش.

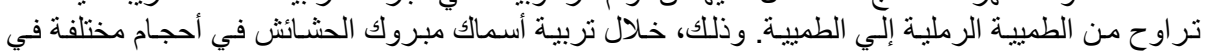

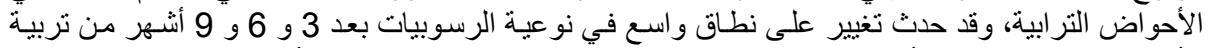

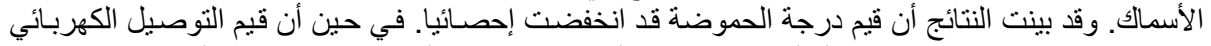

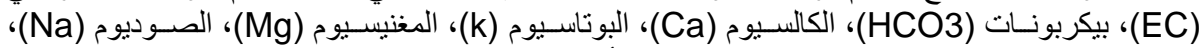

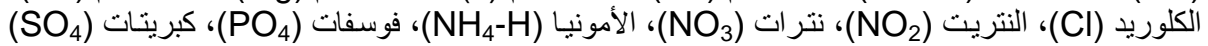

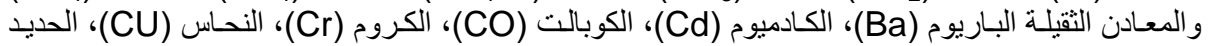

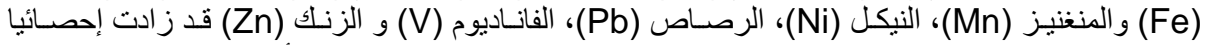

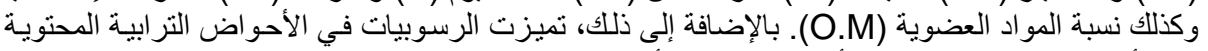

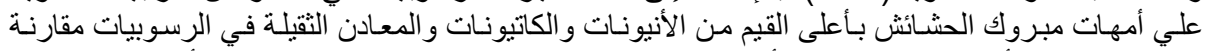

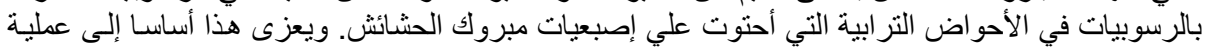

